\title{
The Investigation of the Effects of Melatonin on Electrocardiografic Findings in Rats Undergoing Acute Intense Exercise
}

\author{
Akut Yorucu Egzersiz Yaptırılan Sıçanlarda Melatoninin Elektrokardiyografik Veriler \\ Üzerindeki Etkilerinin Araştırılması \\ (D) Metehan UZUN¹, (D) PInar ÇAKAN² \\ ${ }^{1}$ Çanakkale Onsekiz Mart University Faculty of Medicine, Department of Physiology, Çanakkale, Turkey \\ 2University of Health Sciences Turkey, Hamidiye Faculty of Medicine, Department of Physiology, Istanbul, Turkey
}

\begin{abstract}
Aim: Acute intense exercise causes an additional strain on cardiovascular system. Melatonin has been known as a hormone with cardiovascular protective effects. The aim of this study is to investigate the protective effects of melatonin on cardiovascular changes in rats undergoing acute intense exercise, considering electrocardiogram (ECG) results.

Materials and Methods: The 3-5-month-old 28 Wistar albino rats were used in this study and they were divided into 4 groups. The vehicle injection was applied in the control group without any exercise procedure. The groups of exercise, exercise+melatonin (intraperitoneal injection of melatonin at the dose of $10 \mathrm{mg} / \mathrm{kg}$ before exercise) and exercise+melatonin+luzindole (intraperitoneal injection of luzindole at the dose of $0.4 \mathrm{mg} / \mathrm{kg}$ and melatonin at the dose of $10 \mathrm{mg} / \mathrm{kg}$ before exercise) were run on treadmill until they were tired. ECG recording was performed at the end of the exercise.

Results: A significant increase in heart rate was observed in both exercise groups. The decreasing effect of melatonin on QT and QTc prolongation in the exercise group was reported; however, this effect did not occur in the luzindol administrated group. Melatonin also decreased corticositerone levels, which increased with exercise, independent of receptor. White blood cell and neutrophile counts of the melatonin administrated group were observed to be close to that of the control group.

Conclusion: These results indicate that melatonin can be used as an agent that may decrease unfavorable effects of exercise and improve the quality of exercise.

Keywords: Exercise, melatonin, QT duration, corticosterone

ÖZ

Amaç: Akut yorucu egzersiz kardiyovasküler sistem (KVS) için ilave bir yük oluşturmaktadır. Melatonin ise KVS üzerine koruyucu etkileri olduğu bilinen bir hormondur. Bu çalışma ile akut yorucu egzersiz uygulanan sıçanlarda KVS'de meydana gelen değişikliklerin elektrokardiyografi (EKG) verileri üzerinden değerlendirilmesi ve melatoninin koruyucu etkilerinin araştırılması amaçlandı.

Gereç ve Yöntem: Çalışma 3-5 aylık 28 adet Wistar Albino sıçan üzerinde yürütüldü ve 4 ayrı grup oluşturuldu. Kontrol grubuna sadece taşıyıcı çözelti uygulandı ve herhangi bir egzersiz yapılmadı. Egzersiz, egzersiz+melatonin (egzersizden önce $10 \mathrm{mg} / \mathrm{kg}$ intraperitonal melatonin enjeksiyonu) ve egzersiz+melatonin+luzindole (egzersizden önce intraperitonal 0,4 mg/kg dozda luzindol ve $10 \mathrm{mg} / \mathrm{kg}$ melatonin enjeksiyonu) grupları 5-25 m/ dk hızda koşu bandında yoruluncaya kadar koşturuldu. Egzersiz sonrasında EKG verileri kaydedildi.
\end{abstract}

Address for Correspondence: Metehan UZUN MD, Çanakkale Onsekiz Mart University Faculty of Medicine, Department of Physiology, Çanakkale, Turkey Phone: +90 5435828682 E-mail: metehanuzun@ @otmail.com ORCID ID: orcid.org/0000-0003-1406-5473

Received: 30.06 .2021 Accepted: 05.08.2021

๑Copyright 2021 by the Tekirdağ Namık Kemal University Faculty of Medicine / Namık Kemal Medical Journal published by Galenos Publishing House. 
Bulgular: EKG verilerine göre, her iki egzersiz grubunda kalp hızının anlamlı düzeyde arttığı belirlendi. Melatonin uygulamasının egzersiz grubunda anlamlı düzeyde artan OT ve OTc süresi uzamalarını kısalttığı, luzindol verilen grupta ise melatoninin bu etkisinin ortaya çıkmadığı belirlendi. Melatonin aynı zamanda egzersizle artan kortikosteron seviyelerini reseptör bağımsız bir şekilde azalttı. Egzersizle artan akyuvar sayısı ve nötrofil düzeyleri melatonin grubunda kontrol grubuna yakın düzeyde belirlendi.

Sonuç: Bu sonuçlar melatoninin, egzersizde ortaya çıkabilecek istenmeyen etkileri azaltıcı ve egzersiz kalitesini artırıcı bir ajan olarak kullanılabileceğini göstermektedir.

Anahtar Kelimeler: Egzersiz, melatonin, QT süresi, kortikosteron

\section{INTRODUCTION}

It is known that regular physical activity is extremely beneficial for health. However, high-intensity exercise or exhausting exercise can lead to the formation of reactive oxygen species, causing organ and tissue damage, especially liver and kidney ${ }^{1-3}$. The relationship between exercise and cardiovascular system (CVS) is very important compared to other tissue and organ systems, and many studies have been performed on this subject. It is accepted that regular physical exercise has a reducing effect on the development of atherosclerosis and coronary artery diseases ${ }^{4}$. However, sudden cardiac deaths due to exercise have been reported and the most common underlying hereditary factors have been described as; long OT syndrome, catecholaminergic polymorphic ventricular tachycardia, hypertrophic cardiomyopathy, and arrhythmiogenic right ventricular cardiomyopathy ${ }^{5}$. Therefore, the exercise-QT relationship has attracted the attention of researchers.

The OT interval reflects the total duration of depolarization and repolarization of the ventricular myocardium and varies inversely with heart rate. An increase in heart rate (tachycardia) causes a shortening of the QT interval, while a decrease in rate (bradycardia) causes OT prolongation. Therefore, heart rate should be calculated and corrected OT (OTC) time should be determined to say that the OT duration is within the expected values or is abnormally prolonged. Today, prolongation of the OTc duration is accepted as an age-independent risk factor for sudden death ${ }^{6}$. Exercise can cause arrhythmias by prolonging the QT duration. It is stated that this effect of exercise is associated with cardiac hypertrophy and oxidative damage. Therefore, protective agents are needed against the OT prolonging effect of exercise ${ }^{7}$. Melatonin is one of the candidate molecules that can be used for this purpose.

Melatonin is the most important hormone synthesized from the pineal gland, especially in the dark photoperiod. Although there are many factors affecting the synthesis and release of melatonin, the most important factor is light ${ }^{8}$. Melatonin exerts its effects through high-affinity G-protein coupled receptors of MT1 and MT2. Melatonin receptors have been isolated in various peripheral tissues, including the central nervous system and blood vessels ${ }^{9}$. Luzindole (N-0774), (N-acetyl2-benzyltryptamine) is a pharmacological agent used in scientific research to investigate the role of melatonin in the body and acts as a selective melatonin receptor antagonist. It has approximately 11-25 times greater affinity for the MT2 receptor than for MT1. In animal studies, it was observed that the circadian rhythm related to melatonin was disrupted as a result of giving luzindole to the subjects ${ }^{10,11}$.

In our study, it was planned to investigate the effects of melatonin, a powerful anti-inflammatory and antioxidant known to have protective effects on the cardiovascular system, due to the prolongation of OT duration, activation of inflammatory processes and the emergence of oxidative damage in strenuous exercise.

\section{MATERIALS AND METHODS}

\section{Experimental Animals}

This study was carried out on 28 rats of 3-5 months old Wistar Albino breed at Çanakkale Onsekiz Mart University (ÇOMÜ) Experimental Research Application and Research Center with the permission of ÇOMÜ Animal Experiments Local Ethics Committee, with the number of 2017-04-14. The rats were fed and water ad libitum and housed at $21-22{ }^{\circ} \mathrm{C}$ room temperature throughout the experiment.

\section{Groups}

1. Control Group ( $C, n=7)$ : The rats in this group were injected with saline as the carrier solution of both solutions during the hours when melatonin and luzindole were administered to the other groups. No exercise protocol was applied. They were only kept still on the treadmill for 30 minutes and then electrocardiogram (ECG) measurements were made for 5 minutes under anesthesia and blood samples were taken.

2. Exercise Group ( $E G Z, n=7)$ : The rats in this group were run on a treadmill set at a speed of $5-25 \mathrm{~m} / \mathrm{min}$ until they got tired. When the running time was over, the rats were anesthetized at the sedative level and ECG measurements were made for 5 minutes and blood samples were taken.

3. Exercisez+Melatonin Group (MEL): The rats in this group were injected intraperitoneally with $10 \mathrm{mg} / \mathrm{kg}$ of melatonin 15 minutes before the exercise. For exercise, rats were run on a treadmill set at a speed of $5-25 \mathrm{~m} / \mathrm{min}$ until they got tired. As 
soon as the exercise was finished, the rats were anesthetized at the sedative level and ECG measurements were made for 5 minutes and blood samples were taken.

4. Exercise+Melatonin+Luzindole Group (LUZ+MEL, $n=7)$ : The rats in this group were intraperitoneally injected first with luzindole at a dose of $0.4 \mathrm{mg} / \mathrm{kg}$ and then, 15 minutes later, with melatonin at a dose of $10 \mathrm{mg} / \mathrm{kg} .15$ minutes after the melatonin injection, the animals were run on a treadmill set at a speed of $5-25 \mathrm{~m} / \mathrm{min}$ until they got tired. When the running time was over, the rats were anesthetized at the sedative level and ECG measurements were made for 5 minutes and blood samples were taken.

\section{Preparation of Solutions}

Melatonin was prepared fresh daily to be administered intraperitoneally. For this purpose, melatonin solution was prepared by dissolving the solution containing $2 \%$ ethanol (Absolute GR for analysis, MERCK, Germany) in $1.5 \mathrm{~mL}$ of physiological saline solution ${ }^{12}$.

Luzindole was injected to the rats at a dose of $0.4 \mathrm{mg} / \mathrm{kg}$. For this purpose, luzindole was given daily by dissolving it in physiological saline.

\section{Exercise Protocol}

The rats placed on the treadmill were first run at a speed of 5 $\mathrm{m} / \mathrm{min}$. The speed was gradually increased to $25 \mathrm{~m} / \mathrm{min}$. After the speed of the treadmill reached $25 \mathrm{~m} / \mathrm{min}$, the rats were run until they got tired. When the rats showed signs of fatigue and did not want to run, they were stimulated to run with a mild electrical stimulus. The exercise protocol was terminated for rats that could not run despite the stimulation.

\section{Sedation}

The sedation procedure was performed by intramuscular administration of $40 \mathrm{mg} / \mathrm{kg}$ ketamine $\mathrm{HCl}$ and $4 \mathrm{mg} / \mathrm{kg}$ xylazine for ECG recording only. For this purpose, it was considered sufficient for the rats to remain in light sedation for about 5 minutes.

\section{ECG Recording}

As soon as the rats were removed from the treadmill, sedation was applied and ECG recording was started. From the rats, I, II and III extremity derivations and increased unipolar extremity derivations of $\mathrm{aVR}, \mathrm{aVL}$, and aVF were recorded. ECG recordings were performed non-invasively (Poly-Spectrum 12 channel ECG-System, Poly-Spectrum-8, Neurosoft, 5, Voronin str., Ivanovo, Rusia). ECG recordings were taken as 1 $\mathrm{mV}=20 \mathrm{~mm}$, velocity $75 \mathrm{~mm} / \mathrm{sec}$ and using a filter $(35 \mathrm{~Hz})$. The rats were sedated 5 minutes before the ECG recordings were taken. ECG recordings were taken uninterruptedly for 5 minutes at the same time in all groups. After evaluating the ECG data in general, heart rate, RR duration and QT duration were calculated. In ECG samples 2. RR and OT durations were calculated considering the derivation II and aVR recordings. Calculations were made by determining 3 consecutive RR intervals from each ECG recording. OTc times at the level of milliseconds $(\mathrm{ms})$ were calculated from the determined OT and RR values. The following formulas were used for OTC calculations ${ }^{13}$.

Bazett (OTCB): OT Interval / JRR

Fridericia (QTcF): OT Interval/ $3 \sqrt{ }$ RR

\section{Anesthesia}

The rats whose ECGs were performed were administered general anesthesia. For this purpose, rats were given general anesthesia using ketamine $(60-80 \mathrm{mg} / \mathrm{kg})$ and xylazine $(5 \mathrm{mg} /$ $\mathrm{kg}$ ). Introduction to anesthesia of rats was determined by making reflex control.

\section{Collecting Blood Samples}

Blood samples were taken from rats under anesthesia by cardiac puncture method. Two different blood samples were taken in the study. One of them was used for complete blood count. For this purpose, blood samples were taken into tubes containing EDTA to prevent coagulation and blood count was started without waiting. During this time, the blood samples were kept at $+4{ }^{\circ} \mathrm{C}$. Blood samples taken for corticosterone measurement were taken into serum tubes. These blood samples were centrifuged at 4,000 RPM for 10 minutes in a refrigerated centrifuge at $+4{ }^{\circ} \mathrm{C}$ and the serum part was separated. Serum samples were transferred to eppendorf tubes and placed in storage boxes. And they were stored in a deep freezer at $-80{ }^{\circ} \mathrm{C}$ until analysis.

\section{Obtaining Hematological Data}

Blood count was performed manually using a Thoma slide. For this purpose, the total leukocyte count was determined. Peripheral smear was also made from the blood samples taken, and the neutrophil percentage values were calculated.

\section{Corticosterone Measurement}

The samples were analyzed with the ELISA kit developed to measure corticosterone in rat plasma ${ }^{14}$. Corticosterone measurements were carried out in the Laboratory of İnönü University Faculty of Medicine, Department of Physiology.

\section{Statistical Analysis}

Obtained data were expressed as mean \pm standard error. 
Statistical significance levels of the data were determined using the Statistical Package for the Social Sciences for Windows version 16 (Chicago, IL, USA) program. Multiple group comparisons were made using the Kruskal-Wallis test. The Mann-Whitney U test was used to compare the two groups. All the results obtained and the differences obtained as a result of this comparison were analyzed at $p<0.05$ significance level.

\section{RESULTS}

\section{Duration of Exercise}

In our study, the most dramatic changes were seen in tirelessness durations. While the duration of tirelessness in the exercise group was $14.2 \pm 0.6$ minutes, this value reached $22.5 \pm 0.8$ minutes in the melatonin group $(p<0.001)$. Tirelessness duration decreased to the lowest value of $10.1 \pm 1.1$ in the group administered with luzindole and showed a significant difference with both exercise $(p<0.01)$ and melatonin groups $(p<0.001)$.

\section{ECG Data}

\section{Findings of Heart Rates}

Data showing the heart rate values of all groups are presented in Figure 1. It is seen that the heart rate in the groups varies between 300-405 beats/min. The heart rate value of the MEL+LUZ group was statistically significantly higher than all other groups $(p \leq 0.001)$.

\section{QTc Values}

\section{QTCB Results According to Bazett's Formula}

When OTc values are calculated using Bazett's formula, it is seen that the values of all groups vary in the range of 101213 ms. The QTcB value, which was $101 \mathrm{~ms}$ in the control group, reached $159 \mathrm{~ms}$ in the exercise group. In the group

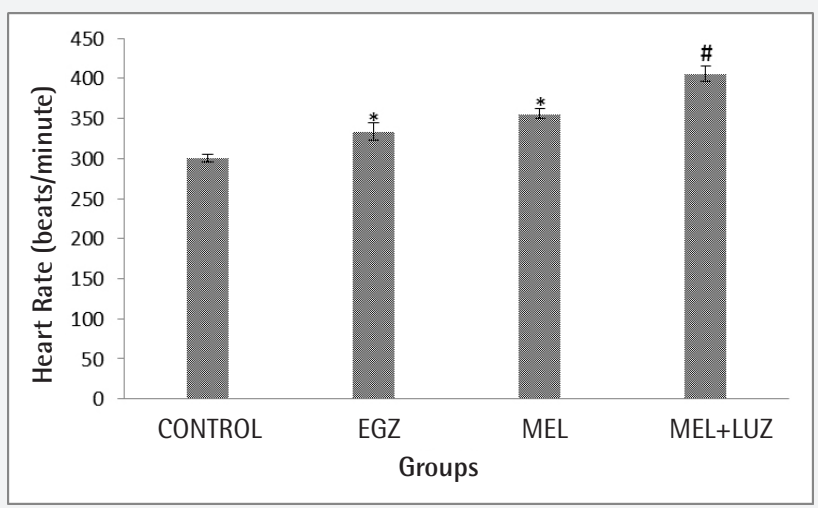

Figure 1. Showing heart rate changes of all groups $\left(^{*}: p<0.05\right.$ according to CONTROL and MEL+LUZ groups, \#: $p \leq 0.001$ according to CONTROL, EGZ and MEL groups) administered melatonin, the OTCB value decreased up to 128 ms and approached the control group value. On the other hand, the MEL+LUZ group showed the highest OTcB value with a value of $213 \mathrm{~ms}$ (Figure 2).

\section{QTc Results According to Fridericia Formula}

It was observed that the change in the QTcF values calculated according to the Fridericia formula was similar to the $\mathrm{OTCB}$ values. Similarly, the lowest value occurred in the control group (77.6 ms), the OTcF value increased $(119.8 \mathrm{~ms}$ ) in the exercise group, melatonin administration caused a decrease in QTcF duration (95.6) and the highest OTcF value in the luzindole group (155.2) was determined (Figure 3).

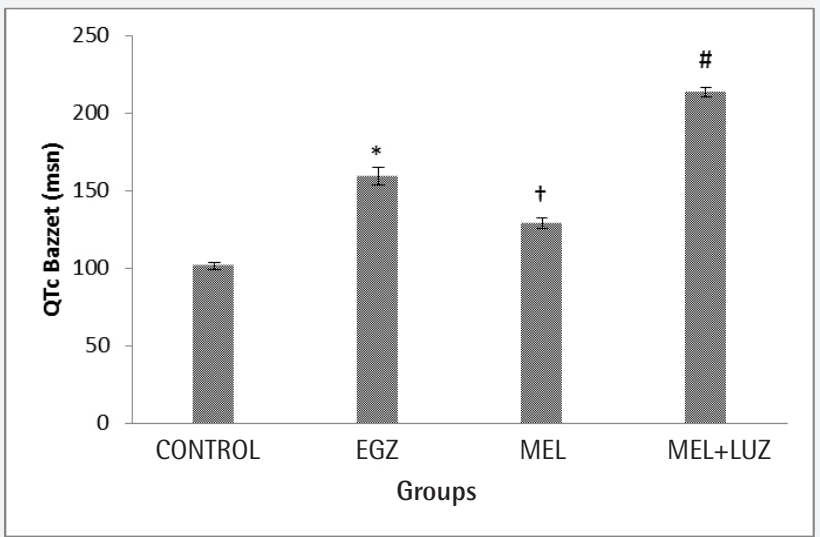

Figure 2. Graphical presentation of QTc values calculated according to the Bazett's formula for all groups $(*: p<0.001$ according to CONTROL, MEL and MEL+LUZ groups, $t$ : $p<0.001$, according to CONTROL, EGZ and MEL+LUZ groups, $\#: p<0.001$ according to CONTROL, EGZ and MEL groups)

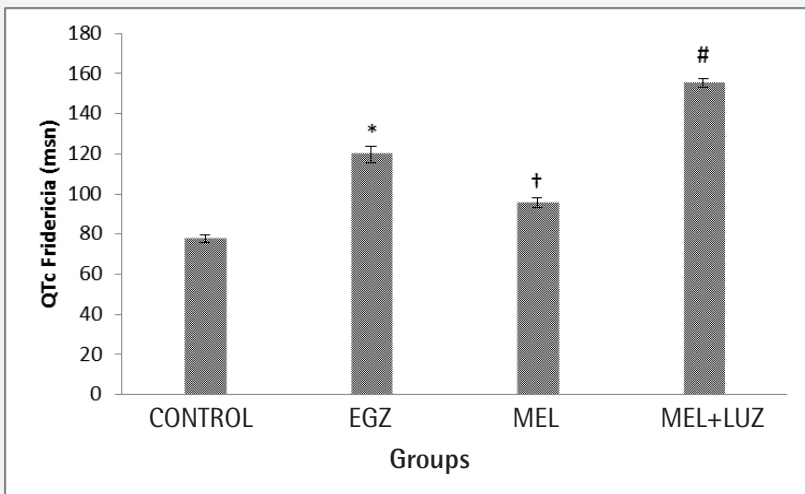

Figure 3. Graphical presentation of QTc values calculated according to the Fridericia formula for all groups $\left({ }^{*}: p<0.001\right.$ according to CONTROL, MEL and MEL+LUZ groups, $t$ : $p<0.001$ according to CONTROL, EGZ and MEL+LUZ groups, $\#: p<0.001$ according to CONTROL, EGZ and MEL groups) 


\section{Corticosterone Values}

Corticosterone values were observed to vary between 249 and $451 \mathrm{ng} / \mathrm{mL}$ in all groups. While the lowest value $(249 \mathrm{ng} / \mathrm{mL})$ was observed in the control group, this value was found to be in the range of $405-451 \mathrm{ng} / \mathrm{mL}$ in all exercised groups (Figure 4).

\section{White Blood Cell Count}

The changes in the white blood cell count values of all groups and the markings showing the statistical significance levels are presented in Figure 5.

\section{Neutrophil Count}

The changes in the neutrophil count values of all groups and the markings showing the statistical significance levels are presented in Figure 6.

\section{DISCUSSION}

In this study, it was revealed that giving melatonin before exercise to rats subjected to acute intense exercise; (a) it reduced prolongations in QTc duration, (b) prevented the increase in white blood cell count (c) but did not cause significant changes in corticosterone levels and heart rate, (d) the QTc and white blood cell count reducing effects of melatonin were blocked by luzindole.

In our study, significant findings were observed in terms of exercise duration. While the rats in the group given melatonin were able to exercise for an average of $22.5 \mathrm{~min}$, this value decreased to $14.2 \mathrm{~min}$ in the group not given melatonin, and to $10.1 \mathrm{~min}$ in the group given luzindole. Thus, it was understood that the rats in the group given melatonin were able to exercise without getting tired for about 2 times longer than the groups that were not given melatonin. This suggests that melatonin increases exercise duration and its effects on exercise duration are receptor dependent. There are reports that melatonin has effects that increase exercise performance. It is stated that the performance of athletes who take melatonin for a long time increases and this is due to the sleep quality-enhancing effect of melatonin ${ }^{15}$. In addition, it has also been demonstrated that taking melatonin before competitions improves athletic performance $^{16}$.

Changes in white blood cell and neutrophil counts were found to be significant in the melatonin group. Both parameters increased significantly in the exercise group compared to the control group, and melatonin administration reduced these values to the same level with the control group. However, it was observed that white blood cell and neutrophil counts reached higher levels when luzindole was given before melatonin administration, even compared to the exercise group. As in

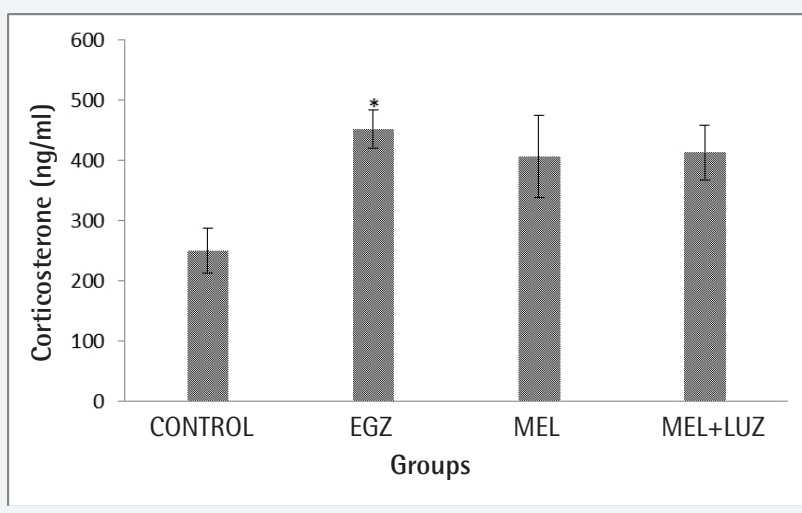

Figure 4. Showing corticosterone values of all groups $(*: p<0.05$ according to CONTROL group)

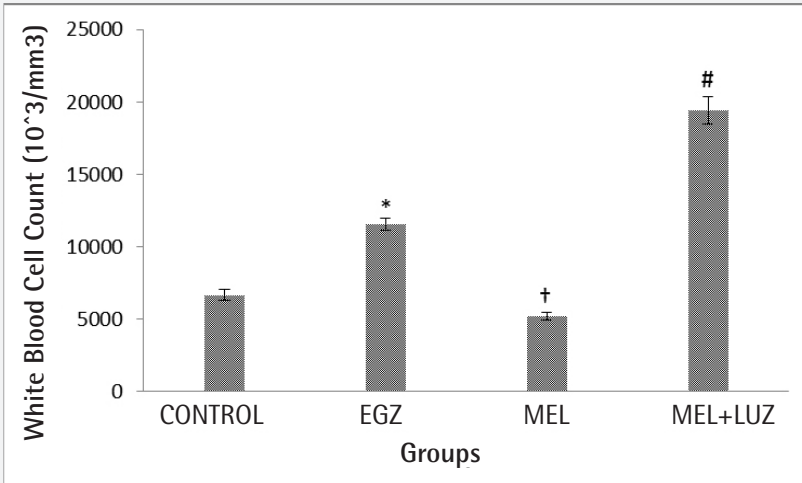

Figure 5. Showing white blood cell count of all groups $(*: p<0.001$ according to CONTROL, MEL and MEL+LUZ groups, + : $p<0.001$, according to EGZ and MEL+LUZ groups, $\#: p<0.001$ according to CONTROL, EGZ and MEL groups)

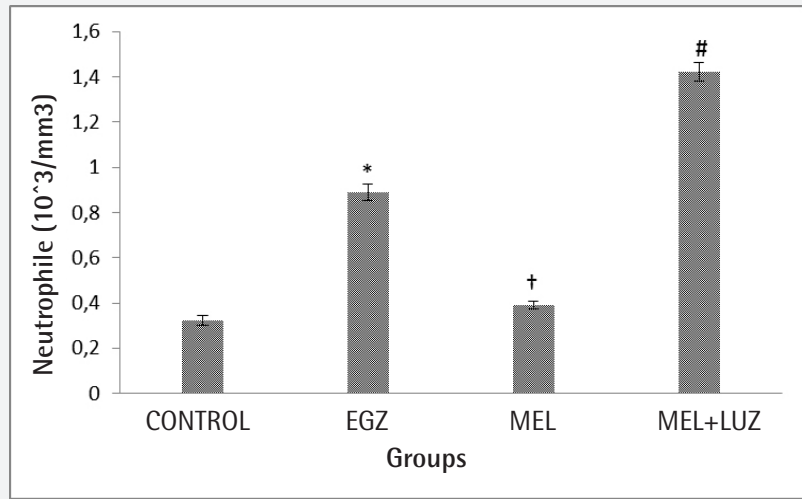

Figure 6. Showing neutrophil counts of all groups $\left(^{*}: p<0.001\right.$ according to CONTROL, MEL and MEL+LUZ groups, $+: p<0.001$ according to EGZ and MEL+LUZ groups, $\#: p<0.001$ according to CONTROL, EGZ and MEL groups) 
the exercise duration value, the effects of melatonin on white blood cell and neutrophil counts were thought to be receptor dependent. It is known that intense exercises disrupt the heart rhythm, stimulate apoptosis, increase oxidative damage, and ultimately cause heart damage ${ }^{17}$. During exercise, the need of the heart and muscle tissue for blood flow increases considerably, so muscle flow changes ${ }^{18}$. Intense exercise causes the aerobic state in the tissues and heart to become anaerobic $^{19}$. In such a situation, the ischemic heart causes an increase in reactive oxygen species, and it is stated that this is the most important factor causing heart damage ${ }^{20}$. Melatonin is known as a very powerful antioxidant. It also has powerful anti-inflammatory effects. Therefore, depending on these effects, it may have prevented the increase in white blood cell and neutrophil counts during intense exercise and may have produced a protective effect against tissue and organ damage.

In our study, corticosterone values measured after exercise were found to be significantly higher in the exercise group than in the control group. There was no significant difference in the melatonin and luzindole groups compared to the exercise and control groups. It is known that exercise is a stress factor and causes the release of corticosterone ${ }^{21}$. Melatonin, on the other hand, has a stress reducing feature as well as many known effects ${ }^{22}$. Therefore, in our study, we planned to investigate the effects of melatonin on corticosterone levels. However, although we determined lower corticosterone levels in the melatonin group, this decrease was not statistically significant. At the same time, we observed that the application of luzindole had no effect. The fact that our study included a one-time acute exercise stress may have caused this result.

Sudden cardiac deaths are seen in young or amateur athletes due to hereditary, structural or electrical characteristics of the heart. ECG data are widely used to investigate and prevent some of these heart-related deaths. ECG findings are especially important in asymptomatic athletes. Another factor that makes ECG data important in athletes is the adaptation of the heart to long-term exercise because, in long-term exercises, an increase in vagal tone occurs with the growth of the heart muscle ${ }^{23}$. T wave inversion, ST segment depression and pathological $\mathbf{Q}$ waves may occur, especially in left ventricular hypertrophy ${ }^{24}$. Another common ECG finding in athletes is early repolarization characterized by elevation of the QRS-ST segment (ST segment) ${ }^{25}$. Other findings that occur in athletes and can be detected by ECG are abnormal T wave inversion, ST segment depression and left bundle branch block ${ }^{26-28}$. We did not find any of the above ECG findings in our study. The reason for this can be that the ECG findings obtained in these studies were obtained from athletes who exercised for a long time and whose cardiovascular systems were adapted to it because our study was not planned as a chronic exercise study.
In our study, heart rate, QT and QTc times were also determined from the ECG data. It was determined that the number of heart beats increased in all three groups that exercised. However, a significant increase was observed in the exercise and melatonin groups compared to the control group, while the heart rate reached 405.9 beats/min in the luzindole administered group, which shows a significant increase compared to all groups. In the OT and OTc data, unlike the heart rate, both parameters in the group given melatonin were at the levels of the control group. On the other hand, the highest values were reached in the group given luzindole. This suggests that the effect of melatonin on QT and QTc times is again receptor dependent.

In the ECG recordings made during exercise, especially the changes related to the ST segment are important. However, it is stated that changes in QT duration are important and even more informative than ST duration ${ }^{29}$. OT duration reflects the ventricular repolarization and depolarization time. It is calculated by measuring the time from the beginning of the QRS to the point where the T wave descends to the isoelectric line. Many factors can affect QT duration, and the most important of them is heart rate. For this reason, the QTc duration according to the heart rate is taken into account instead of the QT duration. Various formulas have been developed for this purpose, and the most common one is the Bazett's formula ${ }^{30}$. However, since the Bazett's formula does not give healthy results at very high and very low heart rates, other formulas have also been developed. Therefore, in our study, OTc times were also calculated according to the Fridericia formula. It was observed that the results obtained in both formulas were similar to each other. Another factor affecting QT duration is gender, and QT duration is higher in females than in males ${ }^{31}$. In order to prevent the gender difference from affecting the results, male rats were used in our study.

The effects of exercise on OT duration are highly variable and in particular, the association of post-exercise cardiac deaths with changes in OT duration have been focused ${ }^{32,33}$. Prolongations in OTc durations after exercise have been reported in other studies $^{34,35}$. Prolongation of the QT duration is very important because it causes dangerous and fatal arrhythmias of the torsade de pointes type. Therefore, agents that can prevent OT prolongation are needed. In our study, melatonin was administered for this purpose and it was found to be effective. It was determined that these effects of melatonin did not occur when luzindole was used as a receptor antagonist. Therefore, it can be said that melatonin has an effect on OT duration and this effect is receptor dependent.

\section{Study Limitations}

In our study, the lack of blood pressure values to support ECG data and the absence of molecular analyses to show possible changes in the heart muscle can be considered as the limitations of the study. 


\section{CONCLUSION}

As a result, melatonin administration reduced the increased stress after exercise, decreased white blood cell and neutrophil levels, prolonged exercise duration, and prevented prolongation in QT and QTc durations. These results show that melatonin can be used as an agent that reduces the side effects that may occur in exercise and increases the quality of exercise.

\section{Ethics}

Ethics Committee Approval: This study was approved by Çanakkale Onsekiz Mart University Local Ethics Committee (decision no: 2017/04-14, date: 27.03.2017).

Informed Consent: It is an animal study.

Peer-review: Externally peer-reviewed.

\section{Authorship Contributions}

Surgical and Medical Practices: M.U., Concept: M.U., Design: M.U., Data Collection or Processing: M.U., P.Ç., Analysis or Interpretation: M.U., P.Ç., Literature Search: M.U., P.Ç., Writing: M.U.

Conflict of Interest: No conflict of interest was declared by the authors.

Financial Disclosure: This study was supported by the Scientific Research Projects Coordination Unit of Çanakkale Onsekiz Mart University (project number: TYL-2017-1219).

\section{REFERENCES}

1. Cruzat VF, Rogero MM, Borges MC, Tirapegui J. Current aspects about oxidative stress, physical exercise and supplementation. Rev Bras Med Do Esporte. 2007;13:304-10.

2. Huang KC, Wu WT, Yang FL, Chiu YH, Peng TC, Hsu BG, et al. Effects of freshwater clam extract supplementation on time to exhaustion, muscle damage, pro/anti-inflammatory cytokines, and liver injury in rats after exhaustive exercise. Molecules. 2013;18:3825-38.

3. Lin $X$, Jiang $C$, Luo $Z, Q u$ S. Protective effect of erythropoietin on renal injury induced in rats by four weeks of exhaustive exercise. BMC Nephrol. 2013;14:130.

4. Thompson PD, Franklin BA, Balady GJ, Blair SN, Corrado D, Estes NA, et al. Exercise and acute cardiovascular events placing the risks into perspective: a scientific statement from the American Heart Association Council on Nutrition, Physical Activity, and Metabolism and the Council on Clinical Cardiology. Circulation. 2007;115:2358-68.

5. Cheung CC, Laksman ZW, Mellor G, Sanatani S, Krahn AD. Exercise and Inherited Arrhythmias. Can J Cardiol. 2016;32:452-8.

6. van de Loo A, Arendts W, Hohnloser SH. Variability of QT dispersion measurements in the surface electrocardiogram in patients with acute myocardial infarction and in normal subjects. Am J Cardiol. 1994;74:1113-8.

7. Javidanpour S, Dianat M, Aliakbari FR, Sarkaki A. The effects of olive leaf extract and 28 days forced treadmill exercise on electrocardiographic parameters in rats. J Res Med Sci. 2018;23:108.

8. Brainard, GC, Gaddyf L, Ruberg FM. Ocular mechanisms that regulate the human pineal gland. In: Advances in Pineal Research, M. Mdler. P. Pevet, eds, 1994.Vol. 8. John Libby. p.415-32.
9. Reppert SM, Weaver DR, Rivkees SA, Stopa EG. Putative melatonin receptors in a human biological clock. Science. 1988;242:78-81.

10. Browning C, Beresford I, Fraser N, Giles H. Pharmacological characterization of human recombinant melatonin $\mathrm{mt}(1)$ and $\mathrm{MT}(2)$ receptors. $\mathrm{Br} J$ Pharmacol. 2000;129:877-86.

11. Dubocovich ML. Luzindole (N-0774): a novel melatonin receptor antagonist. J Pharmacol Exp Ther. 1988;246:902-10.

12. Veneroso C, Tuñón MJ, González-Gallego J, Collado PS. Melatonin reduces cardiac inflammatory injury induced by acute exercise. J Pineal Res. 2009;47:184-91.

13. Ovali MA, Uzun M. The effects of melatonin administration on KCNO and $\mathrm{KCNH} 2$ gene expressions and QTc interval in pinealectomised rats. Cell Mol Biol (Noisy-le-grand). 2017;63:45-50.

14. Cakan $\mathrm{P}$, Ozgocer T, Yildiz S. Development and validation of a corticosterone enzyme immunoassay for rat plasma. Acta Physiologica. 2016;217(Suppl 708):76.

15. Leonardo-Mendonça RC, Martinez-Nicolas A, de Teresa Galván C, Ocaña-

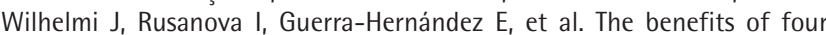
weeks of melatonin treatment on circadian patterns in resistance-trained athletes. Chronobiol Int. 2015;32:1125-34.

16. Escames G, Ozturk G, Baño-Otálora B, Pozo MJ, Madrid JA, Reiter RJ, et al. Exercise and melatonin in humans: reciprocal benefits. J Pineal Res. 2012;52:1-11.

17. Ahmadiasl N, Najafipour H, Soufi FG, Jafari A. Effect of short- and longterm strength exercise on cardiac oxidative stress and performance in rat. J Physiol Biochem. 2012;68:121-8.

18. Atalay M, Laaksonen DE. Diabetes, oxidative stress and physical exercise. J Sports Sci Med. 2002;1:1-14.

19. Michailidis $Y$, Jamurtas $A Z$, Nikolaidis $M G$, Fatouros IG, Koutedakis $Y$ Papassotiriou I, et al. Sampling time is crucial for measurement of aerobic exercise-induced oxidative stress. Med Sci Sports Exerc. 2007;39:1107-13.

20. Powers SK, Jackson MJ. Exercise-induced oxidative stress: cellular mechanisms and impact on muscle force production. Physiol Rev. 2008;88:1243-76.

21. Gong S, Miao YL, Jiao GZ, Sun MJ, Li H, Lin J, et al. Dynamics and correlation of serum cortisol and corticosterone under different physiological or stressful conditions in mice. PLoS One. 2015;10:e0117503.

22. Hill MN, Brotto LA, Lee $\Pi$, Gorzalka BB. Corticosterone attenuates the antidepressant-like effects elicited by melatonin in the forced swim test in both male and female rats. Prog Neuropsychopharmacol Biol Psychiatry. 2003;27:905-11.

23. Sharma $S$, Drezner JA, Baggish A, Papadakis M, Wilson MG, Prutkin JM, et al. International Recommendations for Electrocardiographic Interpretation in Athletes. J Am Coll Cardiol. 2017;69:1057-75.

24. Lakdawala NK, Thune JJ, Maron BJ, Cirino AL, Havndrup O, Bundgaard H, et al. Electrocardiographic features of sarcomere mutation carriers with and without clinically overt hypertrophic cardiomyopathy. Am J Cardiol. 2011;108:1606-13.

25. Tikkanen JT, Junttila MJ, Anttonen O, Aro AL, Luttinen S, Kerola T, et al. Early repolarization: electrocardiographic phenotypes associated with favorable long-term outcome. Circulation. 2011;123:2666-73.

26. Haghjoo M, Mohammadzadeh S, Taherpour M, Faghfurian B, Fazelifar AF Alizadeh $\mathrm{A}$, et al. ST-segment depression as a risk factor in hypertrophic cardiomyopathy. Europace. 2009;11:643-9.

27. Le W, Wheeler MT, Mandic S, Dewey F, Fonda H, Perez M, et al. Addition of the electrocardiogram to the preparticipation examination of college athletes. Clin J Sport Med. 2010;20:98-105.

28. Rowin EJ, Maron BJ, Appelbaum E, Link MS, Gibson CM, Lesser JR, et al. Significance of false negative electrocardiograms in preparticipation screening of athletes for hypertrophic cardiomyopathy. Am J Cardiol. 2012:110:1027-32. 
29. Yu PN, Bruce RA, Lovejoy FW, Pearson R. Observations on the Change of Ventricular Systole (Qt Interval) During Exercise. J Clin Invest. 1950;29:27989.

30. Indik JH, Pearson EC, Fried K, Woosley RL. Bazett and Fridericia QT correction formulas interfere with measurement of drug-induced changes in OT interval. Heart Rhythm. 2006;3:1003-7.

31. Omiya K, Sekizuka H, Kida K, Suzuki K, Akashi YJ, Ohba H, et al. Influence of gender and types of sports training on QT variables in young elite athletes. Eur J Sport Sci. 2014;14(Suppl 1):S32-8.

32. Cappato R, Alboni P, Pedroni P, Gilli G, Antonioli GE. Sympathetic and vagal influences on rate-dependent changes of $\mathrm{OT}$ interval in healthy subjects. Am J Cardiol. 1991;68:1188-93.
33. Chinushi M, Sato A, lijima K, Suzuki K, Hiroshi F, Izumi D, et al. Exerciserelated OT interval shortening with a peaked $T$ wave in a healthy boy with a family history of sudden cardiac death. Pacing Clin Electrophysiol. 2012;35:e239-42.

34. Berger WR, Gow RM, Kamberi S, Cheung M, Smith KR, Davis AM. The QT and corrected QT interval in recovery after exercise in children. Circ Arrhythm Electrophysiol. 2011;4:448-55.

35. Ogedengbe JO, Adelaiye AB, Kolawole OV. Effects of exercise on PR intervals, QRS durations and QTC intervals in male and female students of University of Abuja. J Pak Med Assoc. 2012;62:273-5. 